ANETA KRZEWIŃSKA*

Uniwersytet Łódzki

DOI: $10.26485 / \mathrm{PS} / 2017 / 66.3 / 2$

\title{
SŁABOŚCI I NIEDOSTATKI PROCEDUR DEMOKRACJI DELIBERACYJNEJ
}

\section{Streszczenie}

W artykule zostały omówione dwie kwestie. Po pierwsze, wskazano na cechy systemów demokratycznych, które są krytykowane przez zwolenników demokracji deliberacyjnej. Taka perspektywa pozwoliła na prezentację najważniejszych cech demokracji deliberacyjnej. Charakteryzując ten typ demokracji, odniesiono się również do samej procedury deliberacji, czyli grupowego namysłu nad ważnymi kwestiami o wymiarze społecznym, politycznym i gospodarczym. Po drugie, przeprowadzono krytykę demokracji deliberacyjnej, ale nie odnosząc się do jej filozoficznych założeń, lecz wskazując na problemy, które wynikają ze stosowania właściwych dla demokracji deliberacyjnej procedur. Artykuł kończy prezentacja przyczyn niezwykle rzadkiego wykorzystywania procedur deliberacyjnych w Polsce oraz trudności, z jakimi wiąże się ich realizacja.

Słowa kluczowe: demokracja deliberacyjna, deliberacja, procedury demokracji deliberacyjnej, facylitator

Demokracja deliberacyjna ${ }^{1}$, w której plebiscyty, referenda, wybory, medialne popisy przedstawicieli poszczególnych ugrupowań politycznych są uzupełniane

* Dr, Wydział Ekonomiczno-Socjologiczny, Katedra Metod i Technik Badań Społecznych; e-mail: aneta.krzewinska@uni.lodz.pl

${ }_{1}$ W artykule konsekwentnie używam określenia demokracja deliberacyjna, skłaniając się ku podejściu Marka Czyżewskiego, który w eseju recenzyjnym Demokracja deliberacyjna w Unii Europejskiej i europejska strefa publiczna wyjaśnia: „«Deliberacyjny» pochodzi od «deliberacji», podobnie jak od «integracji» pochodzi «integracyjny» (a nie «integratywny»)" [Czyżewski 
lub zastępowane dyskusjami, zbiorowym namysłem, dogłębnym rozważaniem ważnych kwestii, zrodziła sięjako odpowiedź na niedostatki systemu demokracji przedstawicielskiej. Warto podkreślić, że przedstawiciele demokracji deliberacyjnej krytykują nie tylko błędy, wypaczenia, braki powiązane z ułomną realizacją koncepcji demokratycznej w praktyce, ale również wadliwe założenia „wzorca”, czyli obecnego systemu demokratycznego. I chociaż trudno dziś wskazać na jedną, obowiązującą wersję demokracji deliberacyjnej - bowiem pojęcie to można zastosować do każdej z idei, w której najistotniejszym elementem jest podejmowanie decyzji w wyniku publicznej debaty równych i wolnych uczestników [Bohman 1998: 401] - to jednak każda z tych wersji krytycznie odnosi się do zapośredniczonych form uczestnictwa obywateli w życiu polityczno-społecznym. Przedstawiciele czy propagatorzy demokracji deliberacyjnej przeciwstawiają się ,[...] demokracji agregacyjnej, demokracji racjonalnego wyboru, plebiscytowej, komunitarystycznej, targowej, personalistycznej i wielu innym" [Buksiński 2002: 349]. Dokonując pewnego uogólnienia (zbierając najważniejsze cechy aktualnie obowiązujących systemów demokratycznych bez ich jednostkowych cech wyróżniających), można powiedzieć, że krytykowane jest przede wszystkim to, iż w debatach uczestniczą tylko wybrańcy - przedstawiciele wyborców, którzy nierzadko nie stanowią większości. Dla przeciętnych obywateli udział w demokracji ogranicza się jedynie do oddania głosu w kolejnych wyborach (pozwala to na rozliczenie kandydatów popieranych w poprzednim głosowaniu - przedhużenie ich mandatu lub udzielenie poparcia ich oponentom). Takie chwilowe, powierzchowne i często bezrefleksyjne zachowania wyborców porównywane są do zachowań konsumentów dokonujących wyboru towarów lub usług [por. Wnuk-Lipiński 2004; Bauman 2000]. Nie wkładają wysiłku w poszukiwanie informacji niezbędnych do: podjęcia decyzji, na kogo oddać głos, porównania programów politycznych różnych kandydatów, przeanalizowania konsekwencji zmian, które mają zostać wprowadzone. Jednocześnie obywatele starają się zracjonalizować takie zachowanie poprzez tłumaczenie sobie, że tak naprawdę ich głos niewiele znaczy, nie mają wpływu na sprawy publiczne ${ }^{2}$.

2008: 179]. Określenia „deliberatywny” używam tylko wtedy, gdy piszę o sondażu deliberatywnym (zakładając, że taka nazwa się już przyjęła) lub cytując fragmenty publikacji, w których forma „deliberatywna” została użyta.

2 Wyniki sondażu „Aktualne problemy i wydarzenia” przeprowadzonego przez CBOS w pierwszej połowie stycznia 2016 roku na losowej próbie dorosłych mieszkańców Polski pokazują, że co prawda „[...] poczucie wpływu na sprawy publiczne jest najwyższe od początku lat dziewięćdziesiątych (od czerwca 1992 roku)" [Roguska 2016: 4], jednak nadal tylko 41\% badanych deklaruje poczucie wpływu na sprawy kraju, a 56\% na sprawy swojego miasta/gminy (czyli na 
Zdaniem krytyków demokracji przedstawicielskiej takie postawy wyborców powodują, że również elity polityczne dalekie są od inicjowania debat nad ważnymi problemami społecznymi, gospodarczymi i politycznymi. Zamiast tego skupiają się raczej na stosowaniu ,chwytów marketingowych” mających wpłynąć na pozyskanie zwolenników, analizują sondaże opinii publicznej oraz raporty ze zogniskowanych wywiadów grupowych pozwalające atrakcyjnie przedstawić najważniejsze elementy programu danej partii.

W tym systemie nie zadaje się pytań dotyczących uzasadniania własnych preferencji politycznych, nie prowadzi się debaty, podczas której można zaprezentować własne racje i przekonać do swoich poglądów. David Held podsumowuje, że współczesna demokracja „,...] ma skłonność do ześlizgiwania się w konflikty osobiste, grę sławnymi postaciami, spory o słowa oraz bezwstydne zabiegi polityków o własne korzyści czy ambicje" [Held 2010: 300].

Zwolennicy demokracji deliberacyjnej odnoszą się również do agregatowego charakteru systemów demokratycznych, podważając sensowność mechanizmu sprowadzającego się do prostego sumowania głosów oddanych przez obywateli - bez analizy tego, jakie treści ukryte są za takimi wyborami, jaki punkt partyjnego programu o tym zadecydował, czy miała na to wpływ sytuacja osobista danego wyborcy, a może jego wartości itp. Obywatele są niejako „wyłuskani” z otoczenia, w którym na co dzień funkcjonują, przypisani (czasami sztucznie) do danego okręgu wyborczego, i chociaż podejmując życiowe decyzje, zazwyczaj biorą pod uwagę innych ludzi, to w przypadku wyborów nie konsultują, nie uzgadniają, nie uwzględniają ,,[...] potencjału, motywów, preferencji i interesów innych" [Wasilewski 2007a: 319].

We współczesnych systemach demokratycznych debaty polityczne cechuje krótkotrwałość, a jeśli dopuszcza się do nich obywateli, to często odczuwają oni obcość czy nawet fasadowość lub pozorność tego przedsięwzięcia. Doskonałym przykładem takiej sytuacji jest organizowanie konsultacji społecznych na etapie, w którym decyzje już dawno zapadły, albo gdy nie ma możliwości zrealizowania postulatów uczestników konsultacji. Krytykowane są nie tylko zasady demokracji, ale również ich realizacja, na pierwszy plan wysuwają się: spadająca frekwencja w wyborach, zmniejszająca się chęć uczestnictwa w życiu politycznym, brak zaangażowania ludzi w różne inne formy obywatelskiej aktywności. A im bardziej obywatele wycofują się z życia publicznego, tym większe prawdopodobieństwo,

sprawy lokalne). W sondażu tym zadano dwa pytania dychotomiczne: „Czy Pana(i) zdaniem ludzie tacy jak Pan(i) mają wpływ na sprawy kraju?” oraz „Czy Pana(i) zdaniem ludzie tacy jak Pan(i) mają wpływ na sprawy swojego miasta, gminy?". 
że nie wszystkie głosy zostaną usłyszane, nie wszystkie racje przedstawione, nie wszystkie opinie wniesione do dyskusji.

Zwolennicy demokracji deliberacyjnej uważaja, że brak debaty i kontroli nad istotnymi społecznymi kwestiami jest jedną z głównych przyczyn braku ich skuteczności, prawomocności i sprawiedliwości [Held 2010: 305]. Dlatego to właśnie debata, mająca znamiona deliberacji, ma być sprawnym sposobem podejmowania decyzji. To z kolei ma się przyczynić do podniesienia jakości samej demokracji.

\section{DELIBERACJA - SINE QUA NON DEMOKRACJI DELIBERACYJNEJ}

Demokracja deliberacyjna ${ }^{3}$, zdaniem jej orędowników, ma łączyć w sobie: mocna, akademicką podstawę teoretyczną (badania nad jej stanem i warunkami stosowalności), działania praktyczne (wdrażanie jej procedur), a także ruch społeczno-polityczny zmierzający do jej propagowania [Wasilewski 2007b: 13]. Najważniejsze składniki tej odmiany demokracji - deliberacje (nazywane także: dyskusjami, dialogami, dyskursami, komunikacją dialogowa) - powinien kończyć dobrowolny consensus. Jądrem idei demokracji deliberacyjnej jest bowiem przekonanie, że za decyzjami w sprawach publicznych nie musi stać głosowanie wielomilionowych grup uprawnionych do tego obywateli, ale wystarczy, by decyzja została podjęta w wyniku „procesu argumentacji wolnej od przemocy i przymusu” [Żardecka-Nowak 2008: 31] z udziałem wybranej, niezbyt licznej grupy obywateli. Aby taki proces mógł zaistnieć, należy zwiększyć udział obywateli w życiu publicznym. Udział ten mógłby być zagwarantowany właśnie poprzez prowadzenie pogłębionych dyskusji (deliberacji), które pozwoliłyby na przedstawienie własnych racji i zapoznanie się z poglądami innych. Przy czym w umiarkowanej ${ }^{5}$ wersji

3 Zadaniem tego artykułu nie jest prezentacja historii rozwoju demokracji deliberacyjnej, należy jednak wspomnieć, że projekt ten obecny jest w dyskursie na temat demokracji od lat 80. XX wieku, a za twórcę pojęcia demokracji deliberacyjnej uważa się Josepha Besette'a, chociaż pierwsze wzmianki dotyczące demokracji deliberacyjnej przypisywane są Carol Poteman - propagatorce demokracji ateńskiej. Deliberacja po odpowiednich modyfikacjach miałaby za zadanie pomóc w odrodzeniu się demokracji bezpośredniej i uczestniczącej.

4 Podstawą teoretycznych rozważań filozoficzno-politologicznych odnoszących się do demokracji deliberacyjnej są prace Jürgena Habermasa i Johna Rawlsa [Wasilewski 2007a: 314], o których to autorach pisze się także, że opracowali „,najpełniejsze, względnie niezależne od siebie koncepcje demokracji deliberatywnej" [Żardecka-Nowak 2008: 30].

5 Umiarkowana wersja demokracji deliberacyjnej proponuje, by deliberacje traktować jako formę „przygotowawczą”, pokazującą możliwe rozwiązanie. Co prawda, decyzje powinny być 
demokracji deliberacyjnej postuluje się, aby dotychczasowe procedury rządzenia uzupełnić deliberacjami, a w jej radykalnej ${ }^{6}$ odmianie - aby je zastąpić. Jednocześnie proponuje się, by usuwać z systemów demokratycznych takie procedury, które posiadają wady, są nieskuteczne i nie sprzyjają wypracowaniu wspólnego stanowiska. Nie chodzi przy tym o kreowanie nowych procedur wyborczych, ale o wzbogacanie procedur istniejących tak, ,by przekształcać preferencje obywateli (być może źle poinformowanych) poprzez otwartą i powszechną dyskusję" [Saward 2008: 144]. Ponadto w demokracji deliberacyjnej centralną wartościąjest dobro wspólne, określane w trakcie pracy grupy nad danym problemem. W tym podejściu przyjmuje się, że członek społeczeństwa nie będzie dążył do maksymalizacji swoich dóbr, ale przez satysfakcjonujące współdziałanie z innymi zyskuje szansę na „ekologiczną” realizację również swoich potrzeb. Polityka zatem jawi się jako gra, której rezultat ma zawsze dodatni znak, wygrana jednej osoby nie musi bowiem oznaczać przegranej innej, zyskuje bowiem każda strona biorąca udział w danej rozgrywce. Zazwyczaj nie jest możliwe opracowanie decyzji, które w maksymalnym stopniu zaspokoiłyby potrzeby wszystkich stron debatujących nad danym problemem, dlatego też w przypadku procedur demokracji deliberacyjnej raczej mówi się o ustaleniu stanowiska, które jest w stanie przyjąć większość. W takich sytuacjach efektem deliberacji jest zdefiniowanie obszarów wspólnych, w których zgoda została osiagnięta, obszarów niezgody, w których nie ma szans na porozumienie, oraz obszarów utrzymujących się kontrowersji z zaleceniem odłożenia dyskusji na jakiś czas, być może do chwili, gdy pojawi się szansa na uzyskanie zgody. Podkreśla się, że decyzje podjęte w trakcie deliberacji są decyzjami innymi, a może nawet lepszymi, niż decyzje dokonane bez takiego namysłu. Dzieje się to za sprawą procesu szukania porozumienia, wysłuchania i zaakceptowania racji innych, a także dążenia do ustalenia wspólnego stanowiska. Zachodzi wtedy przeobrażenie świadomości jednostek ułatwiające im rozumienie złożonych problemów, odsłonięcie pewnych ideologii, partykularnych interesów,

podejmowane w oparciu o deliberacyjne ustalenia, ale jednak przez uprawnione do tego ciała przedstawicielskie. Powszechne debaty dla ogółu obywateli należy organizować sporadycznie i tylko w przypadku bardzo ważnych społecznie spraw. Dodatkowo nie wolno narzucać obywatelom obowiązku brania udziału w deliberacjach, jeśli nie mają oni ochoty, wiedzy, kwalifikacji, czasu itp.

6 Wersja radykalna proponuje zupełne zerwanie z instytucjami demokracji przedstawicielskiej i przypisanie demokracji deliberacyjnej społeczeństwu. Instytucje demokracji deliberacyjnej powinny mieć „ostateczne słowo” w sprawie deliberowanych kwestii, a ich postanowienia mogą się zmieniać tylko w wyniku kolejnych deliberacji. Z tych ogólnodostępnych debat nie wolno nikogo wykluczać, bowiem obywatele posiadają naturalną gotowość do brania udziału w takich dyskusjach. 
zdekonstruowanie stereotypowych sądów, a wszystko to wpływa na zwiększenie jakości podejmowanych decyzji.

Procedura deliberacji (deliberation) równoważna jest zatem z pogłębionym i zespołowym namysłem służącym wymianie poglądów, dzieleniu się pomysłami dotyczącymi sposobów rozwiązania danej kwestii, poddawaniu eksperymentom myślowym proponowanych rozwiązań, co w efekcie prowadzi do wyrażenia sądu i/lub podjęcia decyzji, które będą sprawiedliwe. Jest to dyskusja wolnych od przymusu obywateli, którzy w bezstronny sposób rozważają poglądy pojedynczych uczestników, prezentują swoje własne przemyślenia, opowiadają o zdarzeniach ze swojego życia, dzielą się obawami, nadziejami i opiniami dotyczącymi przedmiotu debaty. Oczywiście nie każda dyskusja spełnia cechy narzucone deliberacjom7 O cechach tych pisał m.in. Jürgen Habermas, podkreślając, że tego typu dyskusja ,[...] jest posłuszna regułom, które mają umożliwić bezstronny i spójny osąd w kwestiach praktycznych" [Habermas 2005: 328]. Zaś Jacek Sroka ${ }^{8}$ wymienia postulaty, które musi spełniać procedura deliberacyjna, m.in.:

- argumentatywny charakter dyskusji - debatujący powinni uargumentować wszystkie swoje wypowiedzi, jednocześnie minimalizując liczbę wypowiedzi emocjonalnych;

- wszystkie poglądy, opinie, stanowiska mają zostać wypowiedziane;

- brak jakichkolwiek przymusów związanych z uczestnictwem w debacie, z zapewnieniem prawa do bycia wysłuchanym;

- wielokrotne wracanie do tego samego tematu w kolejnych dyskusjach, elastyczność decyzji, które mogą się zmieniać pod wpływem nowych informacji wziętych pod uwagę w nowej turze deliberacji;

- organizowanie deliberacji na każdy budzący kontrowersje temat.

Wartością dodaną deliberacji jest to, że proces decyzyjny staje się bliższy osobom, których bezpośrednio dotyczą skutki podejmowanych decyzji, co sprzyja wzrostowi poziomu legitymizacji decyzji.

7 Na użytek tego opracowania odwołuję się tylko do jednego ze sposobów definiowania deliberacji, jednak należy pamiętać, że autorzy [zobacz także: Juchacz 2002: 148; Tully 2002: 218; Jakubiak-Mirończuk 2009: 4; Wasilewski 2007b: 26; Zgiep 2013: 52, 54; Bachmann 2004: 51; Walzer 2006: 137, 153] wymieniają różne zestawy cech przypisywanych tego typu dyskusjom. Przemysław Baciak stwierdził nawet, że definicji deliberacji jest tyle, ilu teoretyków zajmujących się deliberacjami [Baciak 2006: 137].

8 Jacek Sroka, charakteryzując deliberację, odwołuje się przede wszystkim do koncepcji Jürgena Habermasa i Johna Dryzka [Sroka 2009: 32-41]. 


\section{PROCEDURY DEMOKRACJI DELIBERACYJNEJ ${ }^{9}$}

Zwolennicy demokracji deliberacyjnej wykraczają poza rozwijanie teoretycznych koncepcji i opracowują również konkretne procedury postępowania określające sposoby prowadzenia deliberacji, wskazówki dotyczące wyboru rodzaju procedur dla danej sytuacji lub grupy uczestników.

W opracowaniach znajdziemy różne propozycje procedur (i wariantów) z opisem sposobów postępowania. I tak, David Held przywołuje sondaże deliberatywne, dni deliberacji i panele obywatelskie [Held 2010: 319-323]. Z kolei w książce pod redakcją Johna Gastila i Petera Levine'a znajdziemy opisy: sondażu deliberatywnego, konferencji consensusu i komórek planowania, sądów obywatelskich, spotkan miejskich XXI wieku, deliberacyjnego planowania miejskiego [Gastil, Levine 2005]. W publikacji Participatory methods toolkit [2005], będącej podręcznikiem opisującym kolejne kroki w stosowaniu różnych technik wykorzystywanych przy partycypacyjnym podejmowaniu decyzji, przywoływane są (oprócz wyżej już wymienionych) procedura Charrette oraz The World Café. Już tak krótki przegląd literatury skłania do sformułowania dwóch istotnych wniosków: 1) istnieje wiele różnych procedur proponowanych w obrębie demokracji deliberacyjnej, wykorzystujących deliberację jako formę podejmowania decyzji; 2) wśród nich można wskazać „flagowe” procedury dla omawianej odmiany demokracji, np. sondaż deliberatywny.

W tej różnorodności trudno o wspólną charakterystykę wszystkich dyskusji wykorzystujących deliberację. Można tylko wskazać na pewne części składowe procedury, które uwypuklają ich wspólne cechy, a także zwracają uwagę na elementy różnicujące. Wśród procedur demokracji deliberacyjnej znajdują się takie, w których niemal w ogóle nie występują elementy ujednolicone (wystandaryzowane $\left.{ }^{10}\right)$ - zwłaszcza gdy nie ma osób prowadzących dyskusję ${ }^{11}$, a uczestnicy

9 W książce Deliberacja. Teoria - metodologia - praktyka używam terminu „techniki deliberacyjne" na określenie takiego sposobu postępowania badawczego, w którym najważniejszym elementem jest deliberacja będąca pogłębioną, zbiorową dyskusją równych sobie i wolnych od przymusu uczestników [Krzewińska 2016]. Jednak na użytek tego artykułu piszę o procedurach, gdyż komponent badawczy związany z gromadzeniem przez socjologów danych generowanych w trakcie deliberacji nie jest istotny dla czynionych tu rozważań.

10 Standaryzację w odniesieniu do procedur demokracji deliberacyjnej można traktować w podobny sposób, jak postrzega się ją w przypadku technik badawczych, a więc procedury oparte na deliberacji mogą charakteryzować się różnym stopniem standaryzacji rozumianej jako ujednolicenie ,[...] czynności i środków” [Lutyński 1994b: 123].

11 Wśród procedur deliberacyjnych wyróżnia się takie, w których dyskusje prowadzą specjalnie przeszkolone do tego osoby nazywane „facylitatorami”. Ich rola sprowadza się do trzech 
sami kierują swoją aktywnością, decydują, jakie tematy i w jakiej kolejności będą omawiać (np. w technice otwartej przestrzeni). Z drugiej strony można mówić o procedurach zawierających elementy o wysokim stopniu standaryzacji (np. w sondażach deliberatywnych w pierwszej fazie badania, przy sondażu zerowym korzysta się ze standaryzowanego kwestionariusza służącego do pomiaru opinii na dany temat). Ujednolicenie związane jest również z przygotowaniem narzędzia, które pozwoli na prowadzenie debaty w sposób uporządkowany. Im mniej standaryzowany przebieg deliberacji, tym scenariusz może przyjmować bardziej otwarta, ogólną formę.

Procedury demokracji deliberacyjnej różnią się także sposobem zapisu wypowiedzi uczestników. W deliberacjach, w których nie ma żadnych dodatkowych, ujednoliconych elementów, zapis ma charakter rejestrujący. W innych debatach ważniejsze niż przebieg dyskusji są wypracowane wnioski - wtedy nie trzeba nagrywać, czy też dokładnie notować pojawiających się argumentów, ale prowadzący dyskusje (najczęściej facylitatorzy) są zobligowani do zapisania końcowych ustaleń w jak najwierniejszy sposób. W przypadku procedur deliberacyjnych, w których istnieją elementy standaryzowane, można rejestrować debatę i/lub dokonywać kategoryzacji odpowiedzi do wcześniej przygotowanych kategorii.

Istnieją takie deliberacje, do których zaprasza się wszystkich, których dana kwestia dotyczy (np. spotkania miejskie XXI wieku). W innych - w sondażu deliberatywnym - deliberacja jest prowadzona z losowo wybranymi uczestnikami, a wyniki dają się przenosić z próby na populację. Czasami (np. w sądach obywatelskich), gdy organizatorom zależy na tym, by wzięli w nich udział typowi przedstawiciele danej grupy, stosuje się dobór celowy. Bywają wreszcie takie deliberacje, kiedy potencjalni uczestnicy dobierają się sami, a organizatorzy mogą tylko wpływać na frekwencję. Same deliberacje organizuje się z jednorodnymi grupami uczestników; kierowane są one na przykład tylko do przeciętnych obywateli (np. mieszkańców danej dzielnicy) lub tylko do grupy celowo dobranych ekspertów. Ale można również deliberować w grupach o różnorodnym składzie, w których spotykają się ,zwykli” obywatele ze specjalistami w danej dziedzinie.

W literaturze opisuje się dyskusje, w których uczestnicy przebywają w tym samym czasie, w tym samym miejscu, widzą się, uczestniczą w tej samej dyskusji,

funkcji: normatywnej (zdefiniowanie celu i zasad debaty), technologicznej (wspieranie komunikacji), przywódczej (wyznaczanie ram dla dyskusji, dbanie o przestrzeganie zasad) [zob. Davis, Chandler 2011: 108-109]. Ale są też takie deliberacje, w których rolę facylitatora przejmuje członek deliberującej grupy, który tylko częściowo odpowiada za przestrzeganie zasad, a do jego zadań należy przede wszystkim wspieranie dyskusji w taki sposób, by grupa mogła zrealizować powierzone jej zadanie. 
oddziałując na siebie nawzajem (mają kontakt bezpośredni) lub też komunikują się za pomocą Internetu (kontakt pośredni).

Deliberacje organizuje się zarówno w grupach związanych z jaką́s instytucja, np. wśród rodziców dzieci uczących się w danej szkole (opinie rodziców na temat edukacji seksualnej ich dzieci [Reykowski 2007: 214-220]), zamieszkujących jakiś teren (osiedle - deliberacja na temat zamknięcia jednej z ulic Poznania; rejon - planowanie przestrzeni w dzielnicy Chinatown w Bostonie; miasto - zarządzanie stadionem w Poznaniu; region - drzewa wzdłuż dróg we Francji; kraj - opinie na temat usuwania śniegu w Japonii; kilkadziesiąt krajów - sondaż deliberatywny z mieszkańcami Unii Europejskiej). Poruszane w deliberacjach sprawy dotyczą całego kontinuum znajdującego się pomiędzy krańcami: sprawy prywatne-sprawy publiczne.

\section{KRYTYKA DEMOKRACJI DELIBERACYJNEJ - PERSPEKTYWA PROCEDURALNA}

Wydawałoby się, że wielość procedur wypracowanych i z powodzeniem stosowanych przez zwolenników demokracji deliberacyjnej pozwala podchodzić z optymizmem do możliwości ich stosowania właściwie zawsze wtedy, gdy należy podjąć decyzję w ważnej społecznie sprawie, i gdy chciałoby się w proces decyzyjny włączyć obywateli. Nie podzielam takiego przekonania ${ }^{12}$, szczególnie gdy projekt wprowadzania procedur demokracji deliberacyjnej odniesiemy do Polski. Jednak nie tylko ja nie jestem optymistką, jeśli chodzi o tę kwestię, nie brakuje wszak krytycznych głosów skupiających się zwłaszcza na założeniach demokracji deliberacyjnej. Na przykład Ian Shapiro pisze: „[...] wątpię, że kiedykolwiek rząd będzie w stanie faktycznie nakłonić ludzi do deliberacji. Może on przyczynić się do tego, że stanie się ona bardziej lub mniej możliwa, ale koniec końców zależy ona przede wszystkim od zaangażowania osób w niej uczestniczących. W założeniu, deliberacja wymaga dobrej woli, pełnej troski, twórczej pomysłowości i dążenia do wypracowania najlepszych rozwiązań. A tego nie można wprowadzić odgórnie" [Shapiro 2006: 66]. Demokracja deliberacyjna nie może stać się powszechnie obowiązującą odmianą demokracji, gdyż zdaniem

12 Moje własne badawcze doświadczenia związane z próbą zastosowania procedur deliberacji nie zawsze kończyły się sukcesem. W trakcie konsultacji społecznych dotyczących nowych murali na terenie Łodzi zostało zaplanowanych kilka spotkań (realizowanych w formie kawiarenki deliberacyjnej) dla mieszkańców okolic, w których miał pojawić się mural. Po dwóch spotkaniach trzeba było zmienić formę tych konsultacji i zastąpić deliberacje wywiadami, ponieważ pomimo intensywnej pracy rekrutacyjnej żaden mieszkaniec nie pojawił się w wyznaczonym miejscu i czasie. 
I. Shapiro niezwykle rzadko spotyka się ludzi, którzy zapomnieliby o własnych interesach i kierując się słabo zdefiniowaną kategorią „dobra wspólnego”, zgodziliby się pracować nad rozwiązaniami, które następnie mieliby wprowadzić odpowiedzialni, słuchający i ufający obywatelom decydenci.

Można wskazać na dwie grupy czynników, które są przyczyną dość rzadkiego stosowania procedur demokracji deliberacyjnej w polskich warunkach. Pierwsza z nich związana jest ze specyfiką polskich warunków społeczno-politycznych, a pewnych wskazówek na ten temat dostarcza literatura dotycząca zaufania, kapitału społecznego, kondycji społeczeństwa obywatelskiego w Polsce. Druga grupa czynników odnosi się do samych procedur, a dokładnie - założeń narzucanych deliberacjom.

Zacznę od prezentacji czynników związanych z niskim poziomem aktywności obywatelskiej Polaków, przyjmując jednocześnie hipotezę, że może być on powiązany z niechęcią do brania udziału również w dyskusjach deliberacyjnych.

\section{Poziom zaufania społecznego i kapitału spolecznego w Polsce}

Zaufanie społeczne to sposób radzenia sobie z niepewnością w sytuacji, w której mamy podjąć działanie związane z jakimś ryzykiem. Nie posiadając wtedy wystarczającej wiedzy ani na temat tej złożonej sytuacji, ani prawdopodobieństwa pojawienia się zdarzeń, których nie jesteśmy w stanie przewidzieć, korzystamy z zaufania społecznego, przyjmując, że inni zachowają się zgodnie z naszymi oczekiwaniami. Robert Putnam - uznając, że zaufanie społeczne jest częścią składową kapitału społecznego - definiuje je w następujący sposób: „[...] zrobię coś dla ciebie teraz, nie oczekując natychmiast niczego w zamian, a nawet cię nie znając, ufając jednak, że za jakiś czas ty lub ktoś inny odwzajemni mi tę przysługę" [Putnam 2008: 226]. Piotr Sztompka podkreśla, że dla sprawnego funkcjonowania społeczeństwa bardzo ważne jest „wytworzenie się kulturowo sankcjonowanego uogólnionego «klimatu» zaufania (lub nieufności)" [Sztompka 2005: 430], a kultura zaufania wiąże się z nagromadzeniem, skumulowaniem doświadczeń i nadaniem im trwałości. Czynniki pozytywnie oddziałujące na wytworzenie kultury zaufania w danym społeczeństwie to: dziedzictwo historyczne, stabilność normatywna, przejrzystość organizacji społecznej, trwałość porządku społecznego, podporządkowanie władzy regułom prawa, realizowanie uprawnień i egzekwowanie obowiązków. Do tego wyliczenia Sztompka dodaje jeszcze cechy przypisane jednostkom, takie jak: elementy osobowości jednostki (np. aspiracje, aktywność, nastawienie na sukces, optymizm) i jej zasoby kapi- 
tałowe (wykształcenie, znajomości, oparcie w rodzinie, stan zdrowia, bogactwo duchowe itp.) [Sztompka 2005: 430-431].

W Polsce, jeśli porówna się ją do innych krajów europejskich, od lat zaufanie znajduje się na dość niskim poziomie ${ }^{13}$. W badaniach CBOS z początku 2012 roku na pytanie: „Czy ogólnie rzecz biorąc, większości ludzi można ufać, czy też w stosunkach z innymi należy być ostrożnym?" tylko $23 \%$ respondentów udzieliło odpowiedzi: „,większości ludzi można ufać”, a aż 74\% zadeklarowało ostrożność w stosunkach z innymi (2\% wskazało odpowiedź „trudno powiedzieć") [Cybulska 2012]. Jeszcze niższy poziom zaufania ${ }^{14}$ wynika z badań Diagnozy społecznej z 2015 roku. Opinia „większości ludzi można ufać” była wskazywana przez $15,2 \%{ }^{15}$ respondentów w roku 2015. Autorzy raportu Diagnoza społeczna, porównując otrzymane rezultaty z badaniami European Social Survey (ESS) z 2012 roku, podkreślają, że pod względem ogólnego zaufania Polacy zajmuja jedno z ostatnich miejsc wśród krajów objętych badaniem (trzecie miejsce od końca przed Portugalią i Bułgarią). Natomiast dystans pomiędzy Polską a Danią (krajem z pierwszego miejsca) jest bardzo duży i wynosi aż 54,8 p.p.

Według sondażu z 2012 roku $^{16}$ niski jest także poziom zaufania Polaków do instytucji publicznych, np. zaufanie do Sejmu i Senatu deklaruje 29\% badanych, do partii politycznych $-20 \%$. Obok partii politycznych największą „nieufność Polaków budzą [...] gazety, Sejm i Senat, rząd, telewizja, a także sądy, urzędnicy administracji publicznej oraz Kościoły innych wyznań" [Cybulska 2012: 22]. Dość wysoki poziom zaufania Polaków do ich własnych rodzin i dość niskie zaufanie do instytucji państwowych można wyjaśnić, odwołując się do rozważań Roberta Putnama: „Zaufanie do innych ludzi jest, logicznie rzecz biorąc,

13 Analizy danych prowadzone w latach wcześniejszych niż tutaj przywoływane pokazuja, że poziom zaufania społecznego w Polsce utrzymuje się - porównując go do innych europejskich krajów - na niskim poziomie. Dodatkowo „[P]rzeciętna ocena funkcjonowania demokracji w Polsce również należy do najniższych" [Słomczyński, Janicka 2008: 41], jeśli porówna się ją z oceną funkcjonowania demokracji w innych krajach UE.

14 Różnice wyników w obydwu badaniach wynikają zapewne z różnic w samej metodologii badania tych kwestii.

15 Procenty oznaczają sumę odsetków odpowiedzi 7-10 na jedenastopunktowej skali od 0 do 10, gdzie „0” miało etykietę „ostrożności nigdy za wiele”, a „10” opisano jako „większości ludzi można ufać".

16 W sondażu w 2012 roku zadano pytanie: „Czy, ogólnie rzecz biorąc, ma Pan(i) zaufanie, czy też nie ma Pan(i) zaufania do wymienionych instytucji?", wymieniając 23 różne instytucje. Respondent mógł wskazać odpowiedź ze skali słownej: „,zdecydowanie mam zaufanie”, „raczej mam zaufanie”, „raczej nie mam zaufania”, „zdecydowanie nie mam zaufania”. 
czymś zupełnie różnym od zaufania do instytucji i władz politycznych. Ktoś może $\mathrm{z}$ łatwością ufać sąsiadom, a nie ufać władzom miejskim i vice versa. Na poziomie empirycznym te dwa typy zaufania mogą wykazywać związek lub jego brak, jednak na poziomie teoretycznym powinny być traktowane oddzielnie" [Putnam 2008: 232].

Zaufanie wraz z normami i powiązaniami pozwalającymi na koordynacje i zwiększenie sprawności działań podejmowanych w społeczeństwie to składnik kapitału społecznego. Kapitał społeczny w Polsce, podobnie jak zaufanie, które możemy traktować jak jego wskaźnik, jest na niskim poziomie. W Diagnozie społecznej znajdziemy informację, że „Skłonność do stowarzyszania się [...] gwałtownie spadła z 30,5 proc. w 1989 r. (World Value Survey) do 14,8 proc. i utrzymała się na tym samym poziomie do dziś (w 2015 r. 13,4 proc.)" [Diagnoza spoleczna 2015: 353]. W badaniach CBOS odsetek respondentów deklarujących dobrowolną i nieodpłatną pracę na rzecz innych wynosił w 2012 roku 32\%, co jest zbieżne z tendencjami, które potwierdzają systematycznie prowadzone przez Stowarzyszenie Klon/Jawor analizy wyników badań odnoszące się do sektora organizacji pozarządowych i do aktywności społecznej. Badania ${ }^{17}$ z 2013 roku pokazuja, że aktywność społeczna Polaków od kilku lat utrzymuje się na podobnym poziomie, w działalność na rzecz organizacji, własnego otoczenia, osób spoza kręgu rodziny i znajomych, grup społecznych, Kościoła lub związku wyznaniowego zaangażowana jest mniej więcej jedna trzecia naszego społeczeństwa (34\%). Tendencje te są zgodne z rezultatami badań $\mathrm{CBOS}^{18} \mathrm{z} 2016 \mathrm{roku}$, z których wynika, że „,...] prawie dwie trzecie dorosłych Polaków (63\%) nie działa w żadnej organizacji o charakterze obywatelskim. Mniej więcej co szósty respondent (16\%) deklaruje, że poświęca swój wolny czas na działalność społeczną w jednej tego typu organizacji, co dwunasty (8\%) działa w dwóch organizacjach, a co ósmy (13\%) - w trzech lub więcej” [Boguszewski 2016: 3-4]. Jeśli porównamy te wyniki z rezultatami badań w innych krajach, to okazuje się, że przeciętny Polak przynależy do 0,14 organizacji, podczas gdy np. Szwed do 2,6, Duńczyk do 2,5, a Norweg do 2,4 [Diagnoza społeczna 2015: 353-354]. Należy również dodać, że 54\% respondentów nigdy nie brało udziału w żadnym

17 Raport Zaangażowanie społeczne Polek i Polaków. Wolontariat, filantropia, 1\% i wizerunek organizacji pozarzadowych podsumowujący badania zrealizowane w 2013 roku przez Stowarzyszenie Klon/Jawor [Adamiak 2014].

18 Wyniki badania przeprowadzonego na początku stycznia 2016 roku na reprezentatywnej próbie losowej dorosłych mieszkańców Polski liczącej 1063 osoby [CBOS. Komunikat z badań 13/2016]. Osoby, które zadeklarowały, że działają w organizacjach społecznych, zapytano, na rzecz ilu organizacji pracują społecznie. 
rodzaju działań obywatelskich, co zostało opisane w Demokratycznym Audycie Polski 2014, w którym zebrano wyniki z różnych badań ${ }^{19}$.

Niski poziom zaufania społecznego w Polsce związany jest $\mathrm{z}$ niewielkim zaangażowaniem obywateli $\mathrm{w}$ działalność organizacji pozarządowych oraz z niską jakością kapitału społecznego. Robert Putnam w następujący sposób pisze o zależnościach pomiędzy tymi elementami: ,[...] ludzie, którzy ufają innym współobywatelom, częściej podejmują się pracy w charakterze wolontariuszy, więcej wpłacają na cele charytatywne, częściej włączają się w politykę i działanie organizacji lokalnych, wykazują większą gotowość do podjęcia obowiązków ławnika, częściej oddają krew, jako honorowi krwiodawcy, rzetelniej wywiązują się z obowiązku podatkowego, są bardziej tolerancyjni dla poglądów mniejszości i przejawiają wiele innych cnót obywatelskich" [Putnam 2008: 230-231]. I można dodać, że prawdopodobnie łatwiej dają się namówić na udział w deliberacjach.

\section{Niska frekwencja wyborcza i referendalna}

Niska aktywność społeczna i obywatelska powiązana jest również z niską frekwencją w wyborach i referendach, szczególnie tych o charakterze lokalnym. Gdy prześledzimy frekwencję, począwszy od 1989 roku, to okaże się, że najwięcej osób głosuje w wyborach prezydenckich (68\% w II turze wyborów w 1995 roku, kiedy to o fotel prezydencki walczyli Aleksander Kwaśniewski i Lech Wałęsa), mniej w wyborach parlamentarnych (tylko w pierwszych wolnych wyborach w 1989 roku frekwencja przekroczyła 60\%), a jeszcze mniej w wyborach samorządowych. Nie więcej niż $1 / 4$ uprawnionych do głosowania skorzystało z możliwości oddania swojego głosu w wyborach do Parlamentu Europejskiego. Tylko w dwóch przypadkach na pięć wiążący był wynik referendów krajowych - w referendum konstytucyjnym (bez wymogu 50\% frekwencji) i w referendum w sprawie przystapienia Polski do UE. Kiedy porównamy frekwencję ${ }^{20} \mathrm{w}$ Polsce z frekwencją w innych europejskich krajach, okaże się, że Polska wyprzedziła tylko: Węgry, Kosowo, Rumunię i Litwę; pierwsze pozycje w rankingu zajmują: Malta (w 2008 roku frekwencja 93,30\%), Luksemburg (w 2009 roku 90,93\%), Belgia (w 2010 roku $89,22 \%)^{21}$.

19 Wykorzystano zarówno sondaż CBOS z 2012 roku, jak i wyniki European Social Survey z 2012 roku.

20 Raport Fundacji Batorego z projektu „Masz Głos, Masz Wybór” zestawia frekwencję w wyborach parlamentarnych w krajach europejskich, które odbyły się pomiędzy 2008 a 2012 rokiem [Sześciło, Cześnik, Markowski 2013].

21 Porównując frekwencję wyborczą w różnych krajach europejskich należy pamiętać o szeregu czynników, które mają na nią wpływ, np. istnienie przymusu wyborczego, częstość głosowań, 
Frekwencja wyborcza i referendalna w Polsce jest zdecydowanie niższa niż w innych krajach europejskich (szczególnie w krajach z tzw. starą demokracja), tylko część obywateli skłonna jest udać się do lokali wyborczych i wrzucić do urny wypełnioną kartę. Dlatego trudno oczekiwać, że mieszkańcy naszego kraju chętnie poświęcą zdecydowanie więcej prywatnego czasu niż w przypadku głosowania (kilka dni) na uczestnictwo w deliberacji.

\section{Niedostępność respondentów w badaniach opinii publicznej}

Niska frekwencja w wyborach, niewielka aktywność społeczna mieszkańców Polski dość często idą w parze z wysokim poziomem odmów w badaniach sondażowych. „Założenie, które mówi o podobieństwie aktów partycypacji sondażowej i wyborczej prowadzi do sformułowania hipotezy, która mówi o tym, że absencja w obu tych obszarach współwystępuje i warunkuje ją ten sam mechanizm" [Grzeszkiewicz-Radulska 2009: 18]. Katarzyna Grzeszkiewicz-Radulska wskazała na szereg elementów składających się na sytuację badawczą - zarówno „tkwiących” w samym respondencie, jak i niezależnych od niego, które mogą mieć znaczenie przy odmowach wzięcia udziału w sondażach opinii. Czynniki wpływające na odmowę udziału w badaniach (mogące mieć znaczenie również w przypadku odmów wzięcia udziału w deliberacji) to: lęk przed przestępczością związany z otwarciem drzwi nieznajomej osobie (czy zapraszającemu do udziału w deliberacji), pogłębiająca się apatia polityczna (,słabnięcie norm w zakresie powinności obywatelskich, [erozja] idei społecznej kooperacji i działania na rzecz wspólnego dobra" [Grzeszkiewicz-Radulska 2007: 187]), wzrost potrzeby prywatności, przesycenie rynku badaniami opinii publicznej i/lub konsultacjami społecznymi.

\section{Brak zainteresowania konsultacjami społecznymi i sprawami lokalnymi}

Z badań CBOS z 2015 roku $^{22}$ wynika, że 49\% respondentów podziela opinię, że ludzie tacy jak oni mają wpływ na sprawy swojego miasta, gminy [Hipsz 2015]. Co prawda, odsetek ten systematycznie wzrasta - bowiem w 1992 roku tylko $16 \%$ badanych żywiło takie przeświadczenie, a w kolejnych latach poparcie dla tego poglądu na zmianę opadało i wzrastało - jednak wniosek dotyczący zwiększającej się aktywności na poziomie lokalnym jest moim zdaniem, przynajmniej

sposób głosowania, liczba mieszkańców, tradycje wyborcze itp. Wysoką frekwencję wyborczą w Belgii i Luksemburgu można wyjaśniać za pomocą obowiązku głosowania, natomiast na Malcie specyfiką tego kraju i niewielką liczbą mieszkańców (niecałe $0,5 \mathrm{mln}$ ).

22 Badanie przeprowadzono techniką CAPI na reprezentatywnej losowej próbie dorosłych mieszkańców Polski w połowie kwietnia 2015. 
w Łodzi, iluzoryczny. Jako osoba biorąca czynny udział w konsultacjach społecznych i obserwująca od kilku lat zaangażowanie łodzian w sprawy miasta, dochodzę do wniosku, że w większości wydarzeń uczestniczą wciąż te same osoby - grupa zaangażowanych aktywistów miejskich. Decydenci lokalni w Łodzi ${ }^{23}$ coraz częściej wsłuchują się w głos mieszkańców, jednak dużą frekwencją cieszą się tylko te konsultacje, które związane są z ciekawymi i zarazem kontrowersyjnymi kwestiami. Zdecydowanie gorzej jest w przypadku systematycznie organizowanych konsultacji, np. w sprawach budżetu miasta ${ }^{24}$.

Mała aktywność mieszkańców na szczeblu lokalnym może wiązać się - jak opisuje to Anna Olech - z kilkoma czynnikami: ze zgeneralizowanym, wielopokoleniowym doświadczeniem ustrojowym, czyli dziedzictwem PRL, z brakiem odpowiednich wzorców wolontaryjnego działania na rzecz wspólnoty, z trudnościami na rynku pracy i niemożnością zaspokojenia podstawowych potrzeb życiowych, z obserwowanym starzeniem się społeczeństwa, które wpływa na mniejsze zaangażowanie w sprawy publiczne, ale również zwiększa wykluczenie cyfrowe i dostęp do informacji na temat lokalnych spraw [Olech 2013: 111-112].

\section{Niewielkie doświadczenie związane z podejmowaniem decyzji w kwestiach społecznych}

Niedostateczne zainteresowanie kwestiami społecznymi, brak uczestnictwa w spotkaniach konsultacyjnych i innych rodzajach zebrań, w trakcie których dochodzi do wymiany poglądów, powoduje, że przeciętny obywatel ma coraz mniej szans na nauczenie się i przećwiczenie trudnej sztuki prowadzenia dyskusji. Wieloletnie praktyki podejmujących decyzje, nie uwzględniające opinii osób, których one dotyczą, wzbudzają nieufność i zwiększają poziom wycofania z obywatelskiej sfery życia. Sytuacji nie poprawia również brak systematycznych działań na rzecz podniesienia „kultury dyskutowania”, chociażby w odniesieniu do uczniów polskich szkół. Przedmioty przygotowujące do zabierania głosu w publicznych debatach, uczące sposobów argumentowania, prezentowania własnych poglądów nadal są prowadzone tylko przy okazji sporadycznie realizowanych projektów. Tymczasem wzory takich zajęć dla dzieci i młodzieży można czerpać

${ }^{23}$ W ciągu kilku ostatnich lat Urząd Miasta w Łodzi organizuje coraz więcej konsultacji społecznych: w 2012 roku było ich 9, w 2013 roku - 4, w 2014 i 2015 roku - 10. Na rok 2016 zaplanowano 7 konsultacji społecznych [http://uml.lodz.pl/konsultacjespoleczne, dostęp: 1.02.2016].

${ }^{24}$ Osoby zainteresowane dokładną analizą frekwencji w łódzkich konsultacjach odsyłam do artykułu E-konsultacje społeczne-teraźniejszość czy przyszłość? Łódzkie doświadczenia związane z prowadzeniem konsultacji społecznych [Krzewińska 2015]. 
chociażby z amerykańskich szkół, w których kładzie się nacisk na umiejętność dyskutowania, a nawet deliberowania ${ }^{25}$.

Należy podkreślić, że niechęć do udziału w konsultacjach, dyskusjach, deliberacjach wynika nie tylko z przeszłych doświadczeń. Obecnie organizowane konsultacje społeczne - których efekty nie przekładają się na decyzje, lub takie, które organizuje się tylko jako działania pozorne w sytuacji, gdy decyzja jest już dawno podjęta - utwierdzają mieszkańców w przeświadczeniu, że tak naprawdę ich zdanie wcale się nie liczy.

Być może brak doświadczeń związanych z grupowym podejmowaniem decyzji, niedostatecznie wykształcona kultura debaty i niechęć do dzielenia się władzą powodują, że niektóre próby organizowania deliberacji kończą się niepowodzeniem. To zwiększa niechęć do brania udziału w podobnych przedsięwzięciach w przyszłości. Nie ma więc skąd czerpać przykładów dobrych deliberacyjnych spotkań i skuteczności decyzji podjętych w wyniku deliberacyjnych dyskusji, co nie pozwala przekonać się do samych procedur.

W dalszej części zaprezentuję elementy odnoszące się bezpośrednio do cech samych procedur demokracji deliberacyjnej. I tak, o ile powyższe punkty można przypisywać przede wszystkim cechom aktywności społecznej Polaków, o tyle poniższa lista zdaje się być bardziej uniwersalna i pokazuje słabości tkwiące w samej procedurze deliberacyjnej.

\section{Miejsce i czas deliberacji}

Stawiam hipotezę, że miejsca, w których najczęściej organizuje się deliberacje, często są obce uczestnikom dyskusji i nie sprzyjają samemu prowadzeniu debaty. W wielu miejscowościach trudno znaleźć odpowiednie sale, które mogłyby

25 Bez trudu można znaleźć szereg projektów dla amerykańskich uczniów wraz z raportami $z$ ewaluacji tych zajęć, $w$ których zamieszczono m.in. scenariusze i tematy do deliberacji, pomoce dla nauczycieli, odpowiednie materiały dla uczniów. Często też przedstawiciele organizacji pozarządowych oferują swoją pomoc w realizacji projektu. Przykładem takiego przedsięwzięcia jest projekt uczenia procedury deliberowania nad ważnymi społecznie tematami realizowany przez trzy organizacje pozarządowe ze Stanów Zjednoczonych Ameryki w kilkunastu krajach, który nosi nazwę Deliberating in a Democracy in the Americas (DDA). Prowadzący zajęcia oraz uczniowie szkół średnich mają okazję poznać założenia deliberacji, przećwiczyć jej zasady w trakcie prawdziwych dyskusji, wymienić poglądy na ważne tematy. W ciągu ośmiu lat realizacji tego projektu deliberowało w sumie ponad 40 tys. uczniów i blisko 600 nauczycieli. Lista tematów deliberacji (do których przygotowano specjalne materiały, scenariusze zajęć) umieszczona jest na stronie internetowej: http://www.dda.deliberating.org/index.php?option $=$ com content\&view=section\&layout=blog\&id= 5\&Itemid=37\&lang=en [dostęp 05.12.2017]. 
zostać wykorzystane na tego typu spotkania, nie byłyby związane z jakimiś ,źle kojarzącymi się" instytucjami i można byłoby je wynająć. Czasami miejsce deliberacji w sposób bezpośredni nawiązuje do tematu, nad którym się dyskutuje (sala obrad Urzędu Miasta Łodzi w dyskusjach o kształcie przestrzennym tego miasta lub foyer filharmonii w deliberacji na temat przyszłości tej instytucji kultury), ale nie zawsze powoduje to, że jest to miejsce oswojone, w którym dobrze czują się zgromadzeni uczestnicy.

W niektórych technikach dokładnie określono wygląd sali przeznaczonej do deliberacji, np. w technice otwartej przestrzeni należy dysponować wystarczająco dużą salą po to, by móc ustawić krzesła w okręgu. Kawiarenki deliberacyjne powinny być prowadzone jeśli nie w kawiarni, to przynajmniej w sali dającej się w kawiarnię ,przekształcić”. Natomiast organizując sądy obywatelskie, trzeba znaleźć spokojne, odosobnione i wygodne miejsce, w którym uczestnicy spędzą kilka dni. Te wymogi mogą wpływać na to, jaka procedura zostanie wybrana, a o jej wyborze nie będzie decydował na przykład temat, potrzeby inicjatorów, ale zaplecze, którym dysponuje organizator.

Uczestnicy deliberacji muszą poświęcić na dyskusję swój prywatny czas, a w porównaniu do większości znanych im obywatelskich „obowiązków” (typu: głosowanie, udział w konsultacjach, udział w badaniu opinii) deliberacje wymagają tego czasu bardzo dużo. Do najkrótszych i najszybszych form należą kawiarenki deliberacyjne trwające nie dłużej niż 2 godziny. Jednak już sondaże deliberatywne, podobnie jak spotkania miejskie XXI wieku, zajmują zazwyczaj weekend. Technika otwartej przestrzeni wymaga przynajmniej trzydniowego zaangażowania. Najdłużej trwają sądy obywatelskie - zaprasza się uczestników na 5-7 dni. Trzeba mieć na uwadze to, że ludzie mogą nie chcieć poświęcać swojego wolnego czasu, urlopu, by dogłębnie rozważać nawet najciekawsze kwestie społeczne. Czynnikiem, który w jakiś sposób wpływa na motywację do wzięcia udziału w tego typu przedsięwzięciach, jest wynagrodzenie, przy czym najczęściej są to kwoty odpowiadające średnim dziennym stawkom, jakie potencjalni uczestnicy otrzymaliby za pracę, gdyby jej nie opuścili. Pojawia się jednak wątpliwość, czy uczestnictwo w deliberacji „wspomagane” wynagrodzeniem nie jest niejako „psuciem” obywatelskiej aktywności, słowem, jak rozstrzygnąć dylemat - niska frekwencja (jak w przedstawianych działaniach o charakterze społecznym, np. konsultacjach) versus ,zawodowi" uczestnicy deliberacji, gotowi dyskutować w zamian za wynagrodzenie ${ }^{26}$.

${ }^{26} \mathrm{Z}$ podobnym zjawiskiem mieliśmy do czynienia w Polsce, gdy zaczęto prowadzić badania za pomocą zogniskowanych wywiadów grupowych. Można było wówczas zauważyć, że dla niektórych badanych częsty udział w FGI stał się dobrym sposobem dodatkowego zarobkowania. 
W Polsce wiele przedsięwzięć badawczych lub społecznych organizuje się niemal „chałupniczo”, bazując na pracy zapaleńców, którym pozwala się na eksperymenty typu deliberacje, pod warunkiem, że będą one bezkosztowe. W sytuacji, gdy budżet jest niewielki lub brak go w ogóle, trudno zapewnić uczestnikom maksymalny komfort: wygodną przestrzeń bez instytucjonalnych asocjacji, odpowiedniej jakości materiały, najwyższej klasy ekspertów wspierających ich wiedzą podczas dyskusji, zwrot kosztów dojazdu czy wypłatę ekwiwalentu za poświęcony czas.

\section{Sposób rekrutacji uczestników (sposoby i kanały informowania)}

Procedury deliberacyjne zakładają różne sposoby rekrutacji uczestników (dobory celowe, losowe, samorzutne itd.), a jednocześnie nie dookreślają i nie różnicują tych metod ze względu na warunki, w jakich mają być prowadzone deliberacje. Trudno znaleźć konkretne wskazówki pokazujące w systematyczny sposób wszelkie możliwe zabiegi rekrutacyjne i dodatkowo służące zwiększeniu szans zakończenia sukcesem procedury pozyskiwania uczestników deliberacji. Jest to trochę jak wiedza „tajemna”, którą najczęściej doświadczeni działacze przekazują tym mniej „zaprawionym w rekrutacyjnych bojach”. W moim odczuciu to najsłabsze ogniwo organizowania deliberacji, szczególnie gdy nasz dobór nie rządzi się żadnymi zasadami, czy to losowości, czy celowości. Moje własne doświadczenie ${ }^{27}$ podpowiada, że najlepszą strategią jest łączenie jak największej liczby źródeł informowania o debatach deliberacyjnych. Przy czym należy podkreślić, że osoby otwarte, łatwo nawiązujące kontakty z innymi, ciekawe nowych doświadczeń i uzyskania nowej wiedzy chętniej wezmą udział w deliberacji niż ludzie zamknięci i słabiej radzący sobie w kontaktach interpersonalnych. Z udziału w deliberacji raczej skorzystają „odważni” obywatele chcący się podzielić swoimi ideami, jednocześnie nie obawiający się wystawienia swoich pomysłów na krytykę innych uczestników. Dodatkowo z poczuciem sprawstwa wychodzą z deliberacji głównie ci, którzy odnieśli sukces (przekonali innych do swoich pomysłów), ale też zrozumieli i zinternalizowali ideę szukania rozwiązań najkorzystniejszych dla dobra wspólnego i w poszanowaniu reguł. Innym uczestnikom może towarzyszyć pewien niedosyt, poczucie straty czasu, a nawet

$27 \mathrm{~W}$ jednej z organizowanych przeze mnie deliberacji (związanej ze zmianą przestrzeni publicznej) wysyłano zaproszenia do członków wspólnot mieszkaniowych, rozdawano zaproszenia, rozwieszano plakaty w miejscach publicznych, umieszczano informacje na stronach internetowych i portalach społecznościowych, posługiwano się newsletterem, korzystano z kontaktów osobistych, rozpuszczając ,wici” dotyczące deliberacji. 
wrażenie całkowitej ,przegranej”. I ci będą w przyszłości unikać takich spotkań. Dodatkowym czynnikiem, zapewne wzmacniającym, jest dysponowanie umiejętnością i doświadczeniem publicznego zabierania głosu oraz dyskutowania.

\section{3. „Trudne" i nudne tematy do deliberowania}

Wydaje się, że tylko kwestie istotne dla danej grupy są w stanie przekonać ludzi do tego, żeby poświęcili swój prywatny czas na dyskusję. Z tego powodu umiejętne sformułowanie tematu, a zarazem zapewnienie, że rezultaty deliberacji będą ważne i doniosłe społecznie, mogą podnieść zainteresowanie uczestnictwem w deliberacjach. A jeśli temat nie wystarczy, może należałoby zastosować inne sposoby, by przyciagnąć uczestników, np. gdy rozważania dotyczące Unii Europejskiej i jej roli na świecie nie wydają się wystarczająco interesujące, należy podkreślić wyjątkowość pierwszego europejskiego sondażu deliberatywnego na ten temat, a dodatkowo sfinansować atrakcyjny, weekendowy pobyt w Brukseli. W wielu deliberacjach czynnikiem ,wabiącym" może okazać się temat, który przekłada się w sposób bezpośredni na życie uczestników i porusza ich emocjonalnie. Znane jest zjawisko NIMBY (Not In My Back Yard), związane z postawą sprzeciwu wobec jakichś inwestycji (najczęściej uciążliwych, typu: droga szybkiego ruchu, lotnisko, wysypisko śmieci, lub przyczyniających się do spadku poczucia bezpieczeństwa, np. domy dla uchodźców, osób uzależnionych od substancji psychoaktywnych, czy też obniżających prestiż okolicy, np. hospicjum) przy jednoczesnym przekonaniu, że inwestycje te są bardzo potrzebne, ale należy umieszczać je w zupełnie innym miejscu. I chociaż zjawisko to jest postrzegane jako negatywne, to jednak może ono wpływać na zwiększenie się aktywności mieszkańców i wyłonienie się lokalnych liderów [Michałowska 2008].

Dodatkowym problemem jest kwestia mniejszej czy większej istotności poszczególnych kwestii dla organizatorów. W związku z tym może dojść do sepizacji, czyli przemilczania lub aktywnego unieważniania pewnych problemów (ważnych dla jakiejś społeczności, a trudnych i przez to marginalizowanych przez decydentów), czy kontrsepizacji, polegającej ,[...] na uprawomocnianiu, ujawnianiu, nagłaśnianiu i czynieniu przedmiotem zainteresowania tego, co inni uznali za nieważne" [Czyżewski, Dunin, Piotrowski 2010: 19]. W każdym przypadku inicjatorzy deliberacji, mając wpływ na wybór tematu debaty, mogą dokonać pewnych, choć czasami niezamierzonych, manipulacji. Remedium na taki stan rzeczy byłoby wprowadzenie zasad popieranych przez zwolenników radykalnej odmiany demokracji deliberacyjnej, czyli przekazanie inicjatywy 
organizowania deliberacji każdemu obywatelowi. Ale z tym wiążą się zupełnie inne problemy, chociażby dotyczące zapewnienia miejsca do deliberacji, odpowiedniej frekwencji itp.

\section{Problematyczność reguł deliberacyjnych}

Procedura deliberacji jest bardzo rygorystyczna dla jej uczestników, bowiem z jednej strony nakazuje trzymać się określonych regul, często wymagając pokonania nawyków, z drugiej zaś wymaga żywego dyskutowania, argumentowania, podawania przykładów. Uczestnicy muszą liczyć się z tym, że w trakcie debaty będą mieli okazję wysłuchać opinii znacząco różniących się od ich własnych poglądów, będą dyskutowali z osobami, które reprezentują inny poziom wiedzy na dany temat.

Sporną kwestią pozostaje, czy należy dopuścić do uczestnictwa w deliberacjach przedstawicieli grup, którzy nie akceptują deliberacyjnego porządku i wiadomo, że ich udział może nie tylko zaburzyć tok dyskusji, ale nawet doprowadzić do zerwania obrad. Wszak otwartość spotkań deliberacyjnych zakłada, że wszyscy mają równy dostęp do dyskusji, co stoi w sprzeczności z tym, że obecność osób, które podważają sensowność tematu debaty, samego procesu deliberowania zdaje się być dużym wyzwaniem dla organizatorów. Zwolennicy umiarkowanej wersji demokracji deliberacyjnej chcieliby dokonywać pewnej selekcji wśród uczestników, a zwolennicy radykalnej odmiany tej demokracji nakazują dopuszczać wszystkich.

Jeśli przyjmie się, że każdy może w dowolnym momencie zainicjować deliberację, a proces deliberowania nad daną kwestią może być „usypiany i wybudzany”, to czy jakiekolwiek sprawy dadzą się uznać za raz na zawsze rozstrzygnięte. Ilu debat potrzeba, by uzyskać pewność co do otrzymanych rezultatów, a co zrobić w sytuacji, gdy kolejne tury przynoszą sprzeczne rozstrzygnięcia? Pytania te są tylko przykładowymi wątpliwościami, z którymi muszą się mierzyć organizatorzy deliberacji. Zwolennicy demokracji deliberacyjnej milczą na ten temat, tak samo jak nie wypowiadają się o problemach, które napotkają ci, którzy inicjują deliberacje na bardzo kontrowersyjne tematy, gdy widać wyraźny podział w społeczeństwie i z góry wiadomo, że nie ma szans na jakiekolwiek uzgodnienie wspólnego stanowiska (np. gdy zwolennicy pro choice i pro life będą dyskutować na temat ustawy o dopuszczalności aborcji). W takich przypadkach jedynym sensownym rozwiązaniem wydaje się być zakreślenie samych obszarów niezgody, co jednak może rozczarować uczestników, bowiem brak konstruktywnego efektu w postaci uzgodnionego stanowiska może zniechęcać do podjęcia wysiłku w kolejnych deliberacjach. 
Deliberacja - kojarzona najczęściej z dyskusjami grupowymi - przybiera bardzo różne postaci w zależności od procedury deliberacyjnej. Trudno oczekiwać, że uczestnicy będą znali różnorodne nazwy tych procedur i wcześniejsze pozytywne doświadczenia $\mathrm{z}$ deliberacją nie staną się wystarczającą zachętą do wzięcia udziału w podobnej, ale inaczej nazwanej debacie. Może się więc okazać, że atrakcyjna dla inicjatorów i organizatorów wielość tych procedur jest przeszkodą w budowaniu społecznej świadomości na temat tej formy dyskusji.

\section{Wypracowane wnioski i ich jakość}

Rezultaty deliberacji nie będą raczej zawierały innowacyjnych, rewolucyjnych, oryginalnych pomysłów, gdyż deliberacje nie służą generowaniu nowatorskich idei (to nie burze mózgów), ale są procedurami pozwalającymi na uwspólnianie perspektyw. Z tego powodu najczęściej prowadzą do stworzenia koncepcji wystarczająco dobrych, choć może zachowawczych. Wyjaśnienie tej ostrożności jest proste: grupa poprze tylko te pomysły, na które byli w stanie zgodzić się wszyscy deliberujący (co nie oznacza, że na wyjściowym etapie dyskusji nie pojawiły się koncepcje znacznie śmielsze i oryginalniejsze niż ostatecznie przyjęte). Wartością i zarazem celem jest tu bowiem consensus, a nie oryginalność idei. Zastanawiające jest również to, że czytając raporty z deliberacji, rzadko kiedy docieramy do materiałów (cytatów) z samej dyskusji. Zadać sobie należy pytanie: czy są one zupełnie nieważne z punktu widzenia opracowanych wniosków, mało interesujące (by nie napisać banalne), a może wyrwanie ich z kontekstu (bez pokazania procesu uwspólniania wniosków) jest zabiegiem bezsensownym z punktu widzenia tworzących raport końcowy. Inną kwestią jest też to, że bardzo rzadko można przenieść wnioski z uczestników na populację, z której oni pochodzą (dzieje się to tylko w sondażach deliberatywnych), bowiem w deliberacjach uczestniczy pewna specyficzna kategoria osób - tych mających swoje zdanie, tych umiejących komunikować własne opinie, tych otwartych na nowe doświadczenia i tych gotowych na podjęcie wysiłku związanego z uczestnictwem w debacie. I wreszcie, tych niereprezentatywnych dla populacji.

Nie ma pogłębionych studiów ani na temat procesów grupowych, które zachodzą podczas deliberacji, ani na temat nieodwracalności zmian w opiniach, które zostały zmienione pod wpływem deliberacji. Nie wiadomo, czy i na ile zaobserwowane zmiany w uczestnikach będą trwałe, albo przez jaki czas będzie się utrzymywał „efekt deliberacji”. Korzystając z koncepcji psychologii społecznej dotyczących problematyki związanej z uprzedzeniami i stereotypami, można ostrożnie przyjać, że efekty deliberacji o tematyce związanej z kwestiami silnie 
polaryzującymi ludzi, emocjonalnie ,gorącymi”, będą mniej trwałe niż wpływ deliberacji organizowanych wokół spraw neutralnych, prowadzonych w grupach o zbliżonych poglądach. Zaś same rezultaty deliberacji bywają wykorzystane na kilka sposobów. Po pierwsze, odgrywają tylko rolę edukacyjną dla uczestników, ponieważ decydenci nie są informowani o tym, że miała miejsce deliberacja i o tym, że wypracowano podczas niej jakieś wnioski. Deliberowanie jest „korzystne" tylko dla uczestników, umożliwiając im rozwijanie umiejętności związanych $\mathrm{z}$ lepszym funkcjonowaniem w społeczeństwie. Osoby uczą się obywatelskości [Wesołowska 2010: 31], związanej z nabywaniem kompetencji pomagających lepiej funkcjonować w systemie demokratycznym i przekładającej się na inne sfery ich życia, takie jak np. działalność w stowarzyszeniach, wolontariat czy uczestnictwo w wyborach. Uczestnictwo w deliberacji ma „stymulować rozwój poznawczy, zwiększać kompetencje komunikacyjne, poprawiać zdolności kooperacyjnego rozwiązywania problemów i uczyć myślenia w kategoriach wspólnego dobra i sprawiedliwości społecznej” [Wesołowska 2010: 31]. Dodatkowo wzrasta wiedza uczestników na temat, wokół którego toczy się dyskusja, szansa na poznanie nowych, nieznanych dotąd punktów widzenia, możliwość uporządkowania informacji, które dotychczas posiadali. Wspólna, zbiorowa praca nad danym rozwiązaniem wzmacnia także wzajemne zaufanie, zmniejsza uprzedzenia, pracuje na rzecz tolerancji i dialogu, co w efekcie może przełożyć się na zwiększenie kapitału społecznego.

Deliberacje pełnią również funkcję konsultacyjną, kiedy wnioski mogą, ale nie muszą być wzięte pod uwagę przy podejmowaniu decyzji. Jeśli pomysły wypracowane przez grupę nie znajdują przełożenia na działanie, to podejmujący decyzje powinni wyjaśnić, z jakiego powodu odstapili od wprowadzenia zaproponowanych rozwiązań. I wreszcie, deliberacje mogą być także ,[...] rzeczywistym procesem podejmowania wiążących decyzji”" [Wesołowska 2010: 30]. W takiej sytuacji decydenci realizują to, co zostało ustalone przez deliberujących obywateli.

\section{Niski poziom akulturacji procedury deliberacyjnej}

Deliberacjom nie towarzyszy żadna pogłębiona refleksja dotycząca tego, na ile są one zbieżne, przystające do danego systemu kulturowego, czy pasują do innych procedur życia społecznego. Miałaby to być refleksja podobna do tej, która była podejmowana $\mathrm{w}$ stosunku do technik badawczych, np. sondażu opinii czy zogniskowanych wywiadów grupowych, gdy pisano o akulturacji ${ }^{28}$ tych badań.

\footnotetext{
28 Zobacz Przybyłowska [1996]; Kubiak [2007].
} 
Wydaje się bowiem, że milczące założenie, iż deliberacje pasują wszędzie tam, gdzie istnieje system demokratyczny, nawet jeśli system ten daleki jest od demokratycznego wzorca ${ }^{29}$, zostało przyjęte na wyrost. Zupełnie pomija się też kwestię istnienia $\mathrm{w}$ danej kulturze tradycji prowadzenia debat, w których uczestnicy darzyliby się wzajemnym szacunkiem, podejmowania działań wymagających wspólnej pracy nad danym rozwiązaniem, czy występowania takich umiejętności, jak zawieranie kompromisów, uwzględnianie zdania innych, rezygnowanie ze swoich racji itp. Wydaje się, że trudno znaleźć przykłady debat na tematy społeczne, polityczne lub gospodarcze, które byłyby na tyle „udane” i znane, że mogłyby stanowić dla Polaków wzorce sztuki dyskutowania. Gdy prześledzi się ostatnie dyskusje dotyczące Trybunału Konstytucyjnego, uchodźców, zaostrzenia prawa do aborcji, to traci się nadzieję na szanse prowadzenia w Polsce debat w deliberacyjnym duchu.

\section{ZAKOŃCZENIE}

Pamiętając o ograniczeniach związanych z samymi procedurami deliberacyjnymi oraz z warunkami kulturowymi, w których są one prowadzone, warto sobie uświadomić, że będą one - niejako ze swojej proceduralnej natury - często i nieomal wszędzie gromadzić tylko wąską grupę obywateli. Doskonale ujął to Michael Walzer, pisząc: ,deliberacja jako taka nie jest zajęciem dla demos. Nie chodzi [...] o to, że zwyczajni ludzie płci obojga są pozbawieni zdolności rozumowania, ale że 300 milionów, a nawet milion czy sto tysięcy, nie może wspólnie rozumować i snuć rozważań - jest to po prostu fizycznie niemożliwe" [Walzer 2006: 160]. Znając ograniczenia związane ze stosowaniem tych procedur, nie wolno również zapominać o pewnych etycznych wątpliwościach, bowiem przyjęcie stanowiska, że deliberacja charakteryzująca się swoistą siłą argumentacyjną może wpływać na uczestników w taki sposób, że pod wpływem grupy mogą zmienić zdanie, rodzi pytanie, na ile możliwe są w jej trakcie manipulacje uczestnikami. Czy decydenci nie otrzymują nowego narzędzia do modyfikowania opinii biorących udział w deliberacji w kierunku przez siebie pożądanym? Może zdarzyć się tak, że umiejętnie (z wykorzystaniem elementów manipulacji) prowadzone spotkanie pozwoli na osiaggnięcie z góry założonych efektów. A jeśli cały ten proces będzie oparty na manipulowaniu opiniami uczestników, to w znaczny sposób zostaną naruszone fundamenty zaufania społecznego.

Warto też przywołać inny pogląd na deliberację. Na przykład według Iana Shapiro [2006] takie debaty mogą pogłębiać różnice w opiniach, ponieważ za-

29 James S. Fishkin wraz z zespołem prowadził sondaż deliberatywny również w Chinach. 
kładają wypowiadanie ich wprost. Obrońcy demokracji deliberacyjnej uważają jednak, że jest to szansa, a nie zagrożenie, bowiem jeśli debaty są powtarzane i wyczerpujące - dzięki czemu wszystkie opinie zostaną przedstawione, przedyskutowane i dogłębnie przeanalizowane - niejako w sposób naturalny pojawia się miejsce na kompromisy, modyfikowanie poglądów [Wasilewski 2007b: 26]. Demokracja deliberacyjna działa na korzyść obywatelstwa, ponieważ ludzie biorący w niej udział stają się twórcami/nośnikami opinii, które są dojrzałe, przemyślane. Wynika to z tego, że w trakcie ich tworzenia mieli szansę skonfrontować je z wieloma innymi punktami widzenia. Oczekuje się, by uczestnicy deliberacji charakteryzowali się obywatelską wielkodusznością, która wyraża się we wzajemnej otwartości i podzielaniu przekonania, że wszyscy podchodzą poważnie do dyskutowanych zagadnień. Jest to jednak pogląd daleki od rzeczywistości. Trudno przyjąć założenie, że w deliberacjach uczestniczą tylko „idealni obywatele”, którzy dla bliżej niesprecyzowanego dobra wspólnego poświęcą swój prywatny czas, aby wypracować rozwiązanie jakiejś kwestii społecznej. A na dodatek zapomną na jakiś czas o własnych - indywidualnych lub grupowych - interesach (albo przynajmniej odłożą je na bok). Będą przestrzegać wszystkich ustalonych reguł deliberacji, okażą się empatyczni, otwarci na poglądy innych, gotowi do udziału w długotrwałym procesie, w którym prosi się ich o racjonalne argumenty, o wypowiedzi pozbawione osądów, stereotypów, uprzedzeń i prywatnych dążeń. Milcząco przyjmuje się, że mamy do czynienia z zaangażowanym i zainteresowanym uczestnikiem skłonnym deliberować zawsze i na każdy temat. Dodatkowo zakłada się, że uczestnicy będą na tyle cierpliwi i gotowi do prowadzenia dyskusji, by doprowadzić do uzgodnienia stanowisk, dostosowując się do wszystkich reguł. Deliberacja, w ujęciu zwolenników demokracji deliberacyjnej, jawi się zatem jako proces niezwykle powolny, uporządkowany, stabilny i właściwie nieprzerwany. Ian Shapiro, krytykując ów proces, podkreśla, że deliberacja ma też swoje koszty, do których zalicza ,[...] stracony czas, opóźnienia i brak decyzyjności, zastój w obliczu potrzeby zmian czy nieuczciwą kontrolę nad porządkiem dyskusji. [...] [D]eliberacja może też przyczyniać się do tego, że poświęca się zbyt wiele uwagi sprawom mało ważnym, podczas gdy należałoby w pierwszej kolejności odpowiedzieć na problemy wymagające podjęcia natychmiastowych działań" [Shapiro 2006: 29]. Wydaje się zatem, że uprawniony jest jedynie ostrożny wniosek, iż demokracja deliberacyjna jest tylko ,[...] pewną nowinką, być może nawet niszą współczesnej teorii demokracji. Wielu badaczy uważa ten sposób myślenia za ciekawy z filozoficznego i teoretycznego punktu widzenia, lecz niepraktyczny, wręcz utopijny, gdy popatrzeć nań z perspektywy «realnej demokracji»" 
[Wasilewski 2007a: 314]. Dlatego też skłonna byłabym raczej przyjąć, że deliberacja pozwalająca na osiągnięcie consensusu może zaistnieć tylko w społeczeństwach o wysokim kapitale społecznym, a w Polsce stosowanie procedur deliberacyjnych należy ograniczyć jedynie do niewielkich społeczności lokalnych, małych grup społecznych, których członkowie zainteresowani są debatą na dany temat.

\section{BIBLIOGRAFIA}

Adamiak Piotr. 2014. Zaangażowanie społeczne Polek i Polaków. Wolontariat, filantropia, 1\% i wizerunek organizacji pozarzadowych. Warszawa: Stowarzyszenie Klon/Jawor. http://civicpedia.ngo.pl/files/wiadomosci.ngo.pl/public/civicpedia/publikacje_okladki_ LAST/20140407_RAPORT_final.pdf[dostęp: 5.10.2014].

Bachmann Klaus. 2004. Konwent o przyszłości Europy. Demokracja deliberatywna jako metoda legitymizacji władzy w wielopłaszczyznowym systemie politycznym. Wrocław: Oficyna Wydawnicza ATUT - Wrocławskie Wydawnictwo Oświatowe.

Baciak Przemysław. 2006. „Internet - Agora XXI wieku? Rozważania w świetle teorii demokracji deliberatywnej autorstwa Jürgena Habermasa". Global Media Journal - Polish Edition 2(2) Fall: 132-147.

Bauman Zygmunt. 2000. Globalizacja. Warszawa: PIW.

Bohman James. 1998. "The coming of age of deliberative democracy". Journal of Political Philosophy 6: 399-423.

Buksiński Tadeusz. 2002. Dylematy demokracji deliberatywnej Johna Rawlsa i Jürgena Habermasa. W: Rozum jest wolny, wolność - rozumna, R. Marszałek, E. Nowak-Juchacz (red.), 347-363. Warszawa: Wydawnictwo IFiS PAN.

Boguszewski Rafal. 2016. Aktywność Polaków w organizacjach obywatelskich. Komunikat z badań CBOS nr 13/2016.

Cybulska Anna. 2012. Zaufanie społeczne. Komunikat z badań CBOS, BS/33/2012.

Czapiński Janusz, Panek Tomasz (red.). 2015. Diagnoza społeczna 2015. Warunki i jakość życia Polaków. www.diagnoza.com [dostęp: 25.01.2016].

Czyżewski Marek. 2008. „Demokracja deliberacyjna w Unii Europejskiej i europejska strefa publiczna". Przegląd Socjologiczny LVII/2: 171-185.

Czyżewski Marek, Kinga Dunin, Andrzej Piotrowski. 2010. Cudze problemy, czyli wstęp do sepologii. W: Cudze problemy. O ważności tego, co nieważne. Analiza dyskursu publicznego w Polsce, M. Czyżewski, K. Dunin, A. Piotrowski (red.), 5-22. Warszawa: Wydawnictwa Akademickie i Profesjonalne.

Czapiński Janusz, Panek Tomasz (eds.). 2005. The deliberative democracy handbook. Strategies for effective civic engagement in the twenty-first century. San Francisco: Jossey--Bass.

Davies Todd, Reid Chandler. 2011. Online deliberation design: Choices, criteria, and evidence. W: Democracy in motion: Evaluating the practice and impact of deliberative civic engagement, T. Nabatchi, M. Weiksner, J. Gastil, M. Leighninger (eds.), 103-131. New York: Oxford University Press. 
Elliott Janice, Sara Heesterbeek, Carolyn J. Lukensmeyer, Nikki Slocum. 2005. Participatory methods toolkit. A practitioner's manual. The King Baudouin Fundation and the Flemish Institute for Science and Technology Assessment. www.kbs-frb.be [dostęp: 20.05.2010].

Grzeszkiewicz-Radulska Katarzyna. 2007. „Obywatel jako respondent?”. Przegląd Socjologiczny LVI/1: 175-202. Łódź.

Grzeszkiewicz-Radulska Katarzyna. 2009. „Respondenci niedostępni w badaniach sondażowych". Analizy i próby technik badawczych w socjologii XII. Łódź: Wydawnictwo Uniwersytetu Łódzkiego.

Habermas Jürgen. 2005. Faktyczność i obowiazywanie. Teoria dyskursu wobec zagadnień prawa i demokratycznego państwa prawnego. Warszawa: Wydawnictwo Naukowe Scholar.

Held David. 2010. Modele demokracji. Kraków: Wydawnictwo Uniwersytetu Jagiellońskiego.

Hipsz Natalia. 2015. 25 lat państwa obywatelskiego. Społeczne oceny samorządności terytorialnej. Komunikat z badań CBOS nr 69/2015.

Jakubiak-Mirończuk Aneta. 2009. Model tworzenia prawa w Polsce po reformie Better Regumation a idea demokracji deliberatywnej. ZNZE WSIiZ 3(110): 1-40.

Juchacz Piotr W. 2002. Idea demokracji deliberatywnej. W: Indywidualizm, wspólnotowość, polityka, M.N. Jakubowska, A. Szahaj, K. Arbiszewski (red.), 147-162. Toruń: Wydawnictwo UMK.

Kotnarowski Michal, Radosław Markowski, Michal Wenzel, Marta Żerkowska-Balas. 2014. Demokratyczny Audyt Polski. Warszawa: Centrum Studiów nad Demokracją, SWPS. http:// bs.net.pl/sites/default/files/media/rozne/demokratyczny_audyt_polski_2014_final_0.pdf [dostęp: 10.11.2016].

Krzewińska Aneta. 2015. E-konsultacje spoteczne - teraźniejszość czy przyszłość? Łódzkie doświadczenia zwiazane z prowadzeniem konsultacji społecznych. W: E-społeczeństwo w Europie Środkowej $i$ Wschodniej. Teraźniejszość i perspektywy rozwoju, S. Partycki (red.), 272-287. Lublin: Wydawnictwo KUL.

Krzewińska Aneta. 2016. Deliberacja. Teoria - metodologia - praktyka. Łódź: Wydawnictwo Uniwersytetu Łódzkiego.

Kubiak Anna. 2007. „Destrukcja procesu akulturacji badań sondażowych w Polsce”. Przegląd Socjologiczny LVI/1: 61-78.

Lutyński Jan. 1994. Ankieta i jej rodzaje na tle podziału technik otrzymywania materiałów. W: Metody badań społecznych. Wybrane zagadnienia, Lutyński Jan, 110-150. Łódź: ŁTN.

Michałowska Elżbieta. 2008. „Syndrom NIMBY jako przykład samoorganizacji społecznej na poziomie lokalnym". Studia Regionalne i Lokalne 1(31): 60-80.

Olech Anna. 2013. Kiedy mieszkańcy uczestnicza w podejmowaniu decyzji. W: Przepis na uczestnictwo. Diagnoza partycypacji publicznej w Polsce, tom II, A. Olech (red.), 109-122. Warszawa: Instytut Spraw Publicznych.

Przybyłowska Ilona. 1996. „Proces akulturacji sondaży opinii publicznej w Polsce”. Przeglad Socjologiczny XLV: 125-141.

Putnam Robert D. 2008. Samotna gra w kręgle. Upadek i odrodzenie wspólnot lokalnych w Stanach Zjednoczonych. Warszawa: Wydawnictwa Akademickie i Profesjonalne.

Reykowski Janusz. 2007. „Procesy grupowe a rozwiązywanie antagonistycznych konfliktów: Czy idea demokracji deliberatywnej może mieć psychologiczny sens?”. Psychologia Spoteczna 202 (04): 97-119.

Roguska Beata. 2016. Aktywność spoleczno-polityczna Polaków. Komunikat z badań nr 16/2016. Warszawa, CBOS. 
Saward Michael. 2008. Demokracja. Warszawa: Wydawnictwo Sic!

Shapiro Ian. 2006. Stan teorii demokracji. Warszawa: PWN.

Słomczyński Kazimierz M., Janicka Krystyna. 2008. Strukturalne uwarunkowania postaw prodemokratycznych: Polska na tle innych krajów. W: Strukturalne podstawy demokracji, A. Rychard (red.), 15-46. Warszawa: Wydawnictwo IFiS PAN.

Sroka Jacek. 2009. Deliberacja i rzadzenie wielopasmowe. Teoria i praktyka. Wrocław: Wydawnictwo Uniwersytetu Wrocławskiego.

Sześciło Dawid, Mikołaj Cześnik, Radosław Markowski. 2013. Obywatele $i$ wybory, raport Fundacji Batorego w projekcie „,Masz głos, masz wybór”. http://www.maszglos.pl/wp-content/uploads/2013/06/Raport-Obywatele-i-wybory-Dawid-Szescilo-Mikolaj-CzesnikRadoslaw-Markowski-Warszawa-czerwiec-2013.pdf [dostęp: 20.01.2016].

Sztompka Piotr. 2005. Zaufanie. W: Encyklopedia Socjologii. Suplement. Warszawa: Oficyna Naukowa.

Tully James. 2002. "The unfreedom of the moderns in comparison to their ideals of constitutional democracy". Modern Law Review 65(2): 204-228.

Walzer Michael. 2006. Polityka i namiętność. O bardziej liberalny egalitaryzm. Warszawa: Muza SA.

Wasilewski Jacek. 2007a. Demokracja deliberatywna: stanowiska i nadzieje. W: Konflikty międzygrupowe: przejawy, źródła i metody rozwiąywania, U. Jakubowska, K. Skarżyńska (red.), 313-334. Warszawa: Wydawnictwo SWPS Academia.

Wasilewski Jacek. 2007b. Czy demokracja deliberatywna naprawi współczesną demokrację? W: Konflikt i porozumienie. Psychologiczne podstawy demokracji deliberatywnej, J. Reykowski (red.), 13-35. Warszawa: Wydawnictwo SWPS Academia.

Wesolowska Elżbieta. 2010. Deliberatywne rozwiązywanie konfliktów wartości. Wielość dróg do porozumienia. Olsztyn: Wydawnictwo Uniwersytetu Warmińsko-Mazurskiego.

Wnuk-Lipiński Edmund. 2004. Świat międzyepoki. Kraków: Wydawnictwo Znak.

Zgiep Marcin. 2013. „Namysł - rozmowa - działanie. Teoretyczny model publicznej deliberacji”. Przeglad Socjologiczny LXII/4: 43-65.

Żardecka-Nowak Magdalena. 2008. „Demokracja deliberatywna jako remedium na ponowoczesny kryzys legitymizacji władzy". Teka Komisji Politologii i Stosunków Międzynarodowych 3: 29-40.

Aneta Krzewińska

\title{
THE LIMITATIONS AND SHORTCOMINGS OF DELIBERATIVE DEMOCRACY PROCEDURES
}

\begin{abstract}
This article presents two main issues. Firstly, it shows the characteristics of democracy which are criticised by supporters of deliberative democracy. This perspective makes it possible to present the main attributes of deliberative democracy. The characteristics of this type of democracy refer to the procedures of deliberation, as a general reflection on important social, political, and economic
\end{abstract}


issues. Secondly, the paper criticises deliberative democracy without references to philosophical background, but shows the problems which are related to the implementation of the appropriate the deliberative democracy procedures.

The article concludes with the presentation of an extremely rare application of the procedures of deliberative democracy in Poland, and the troubles connected with its realisation.

Keywords: deliberative democracy, deliberation, procedures of deliberative democracy, facilitator 